\title{
Immunochemical Characterization of a Polysaccharide Antigen of Bacteroides fragilis with an IgM Monoclonal Antibody
}

\author{
By JOHN H. REID, ${ }^{*} \uparrow$ SHEILA PATRICK ${ }^{2}$ AND SOAD TABAQCHALI ${ }^{1}$ \\ ${ }^{1}$ Department of Medical Microbiology, St Bartholomew's Hospital Medical College, \\ London ECIA $7 B E$, UK \\ ${ }^{2}$ Department of Microbiology and Immunobiology, The Queen's University of Belfast, \\ Grosvenor Road, Belfast BT12 6BN, UK
}

(Received 4 March 1986; revised 23 July 1986)

\begin{abstract}
An IgM mouse monoclonal antibody $(\mathrm{McAb}) \mathrm{Bf} 4$ was produced to a surface polysaccharide of Bacteroides fragilis NCTC 9343. Immunoblotting showed that McAb Bf4 reacted strongly with a high molecular mass structure which was sensitive to oxidation with periodate but resisted protease treatment. An inhibition enzyme-linked immunosorbent assay (ELISA) indicated that $\mathrm{McAb} \mathrm{Bf} 4$ did not cross react with the sixteen Bacteroides species and strains tested. Cells of $\boldsymbol{B}$. fragilis NCTC 9343 recovered from the various interfaces of a Percoll discontinuous density gradient were tested in the inhibition ELISA. Bacteria from the $0-20 \%, 20-40 \%$ and $40-60 \%$ interfaces inhibited the ELISA; however, cells from the $60-80 \%$ interface did not. Electron microscopy with immunogold labelling showed that McAb Bf4 did not react with the extracellular fibrous network on bacteria recovered from the $0-20 \%$ interface, or the extracellular electron dense layer on cells from the 60-80\% interface; however, it was associated with a surface structure on cells from the $20-40 \%$ interface. Growth in vivo did not enrich for bacteria with this structure.
\end{abstract}

INTRODUCTION

Bacteroides fragilis is the most common Gram-negative anaerobic organism isolated from clinical specimens (Gorbach \& Bartlett, 1974; Duerden, 1980). However, the factors responsible for the enhanced virulence of this species are unknown despite the development of a number of models for studying the pathogenic mechanisms of bacteroides (Hofstad, 1984). Previous reports have suggested that the capsular polysaccharide of $B$. fragilis may represent a virulence factor (Onderdonk et al., 1977; Connolly et al., 1984).

A number of $B$. fragilis surface antigens have been identified (Kasper, 1976; Babb \& Cummins, 1978; Cousland \& Poxton, 1983; Lambe et al., 1984; Weintraub et al., 1985), but little is known about the distribution and expression of these structures. Variation in the degree of capsulation of $B$. fragilis occurs during passage in vitro and in vivo (Kasper et al., 1980; Patrick \& Reid, 1983; Patrick et al., 1984). Cells of $B$. fragilis with different sizes of capsule can be separated on a Percoll density gradient and appear to differ structurally when examined by electron microscopy (Patrick et al., 1986). The relationship between the surface structures observed by us and either the surface polysaccharide described as 'capsule' by Kasper (1976) or the glycocalyx reported by Lambe et al. (1984) is unknown. Characterization of these antigens using highly specific monoclonal antibodies (McAbs) and immunochemical techniques, e.g. immunoblotting and electron microscopy with immunogold labelling, will provide a way of comparing the surface structures identified by different research groups. McAbs have been produced to rough LPS molecules of B. fragilis (Linko-Kettunen et al., 1984) and a high molecular mass surface structure on $B$. fragilis (Reid et al., 1985).

\footnotetext{
$\dagger$ Present address: Coralab Research, Huntingdon Road Laboratories, Cambridge CB3 ODJ, UK.

Abbreviations: McAb, monoclonal antibody; TBS, Tris-buffered saline; CB, cacodylate/ $\mathrm{HCl}$ buffer; PCP, phenol-chloroform-petroleum.
} 
In this study immunoblotting was used to define the immunochemical nature of the structure recognized by $\mathrm{McAb} \mathrm{Bf} 4$ and an inhibition enzyme-linked immunosorbent assay (ELISA) was used to determine the specificity for Bacteroides strains and species. The distribution of the $\mathrm{Bf} 4$ epitope on $B$. fragilis populations grown in vitro and in vivo was investigated using immunofluorescence and electron microscopy with immunogold labelling.

\section{METHODS}

Bacterial growth conditions. The Bacteroides strains used in this study were as follows: B. fragilis NCTC 9343 from the Department of Microbiology and Immunobiology, the Queen's University of Belfast, UK; $\boldsymbol{B}$. fragilis GNAB 4 from the Department of Bacteriology, Edinburgh University Medical School, UK; $B$. ovatus ATCC 8483 , B. distasonis ATCC 8503, B. thetaiotaomicron NCTC 10582, B. fragilis ATCC 23745, NCTC 9344, NCTC 10584, NCTC 8560 and clinical $B$. fragilis isolates Bf12, Bf17, Bf18, Bf19, Bf20, Bf21, Bf25 and Bf 30 from the Department of Medical Microbiology, St Bartholomew's Hospital Medical College, London, UK. B. fragilis strains grown to late exponential phase in defined broth (van Tassell \& Wilkins, 1978) or on horse blood agar plates were incubated at $37^{\circ} \mathrm{C}$ in an anaerobic chamber (Forma) with an atmosphere of $80 \%(\mathrm{v} / \mathrm{v}) \mathrm{N}_{2}, 10 \%(\mathrm{v} / \mathrm{v}) \mathrm{H}_{2}$ and $10 \%(\mathrm{v} / \mathrm{v}) \mathrm{CO}_{2}$. Identification was confirmed using the API system.

Production of $M c A b s$. A BALB/c mouse was immunized with whole cells of $B$. fragilis NCTC 9343 . The mouse was inoculated intraperitoneally each week for 3 weeks with $0.2 \mathrm{ml}$ of a bacterial suspension of $1.0 \times 10^{8} \mathrm{c}$.f.u. in one-quarter strength Ringer's solution, and an additional inoculation of $0.2 \mathrm{ml}$ was given $4 \mathrm{~d}$ before fusion. Spleen cells from the immunized mouse were fused with $x 63 \mathrm{Ag}-8.653$ myeloma cells using the polyethylene glycol fusion technique (Lemke et al., 1978). Hybrid cell lines were selected in RPMI 1640 medium containing hypoxanthineaminopterin-thymidine and $15 \%(\mathrm{v} / \mathrm{v})$ foetal calf serum (Gibco). Hybridoma culture supernate was screened for antibody to $B$. fragilis NCTC 9343 by ELISA (see below). Hybridoma culture supernate was used in all experiments.

The hybridoma cell line $\mathrm{B} 44$ was cloned using a limiting dilution method and $\mathrm{BALB} / \mathrm{c}$ macrophages were used to assist the growth of hybridoma clones. Cells were concentrated by centrifugation and $1 \mathrm{ml}$ samples stored at $-80^{\circ} \mathrm{C}$ in growth medium containing $15 \%(\mathrm{v} / \mathrm{v})$ foetal calf serum and $10 \%(\mathrm{v} / \mathrm{v})$ dimethyl sulphoxide. Hybridoma cells from this stock were used to produce large quantities of hybridoma Bf4 culture supernate.

ELISA. An indirect ELISA was used to screen for McAb producing hybridoma cell lines. Wells of PVC microtitre plates (Becton and Dickenson) were each coated with bacteria $\left(1 \times 10^{6}\right.$ cells ml $\left.^{-1}\right)$ suspended in $50 \mathrm{mM}$ sodium carbonate buffer, $\mathrm{pH} 9 \cdot 6$. The plates were incubated at $37^{\circ} \mathrm{C}$ for $2 \mathrm{~h}$ and washed three times with $50 \mathrm{~mm}$ sodium phosphate buffer, $\mathrm{pH} 7 \cdot 4$, containing $150 \mathrm{~mm}-\mathrm{NaCl}(\mathrm{PBS})$ and $0.05 \%(\mathrm{v} / \mathrm{v})$ Tween 20 . Plates were stored at $-20^{\circ} \mathrm{C}$.

Hybridoma culture supernate $(100 \mu \mathrm{l})$ was added to each well, and the plates were incubated at $37^{\circ} \mathrm{C}$ for $1 \mathrm{~h}$ and washed as before [dilutions, if required were made in PBS containing $1 \%(\mathrm{w} / \mathrm{v})$ bovine serum albumin (BSAPBS)]. Goat anti-mouse IgM (Mu chain specific) and IgG-alkaline phosphatase conjugates (Tago) diluted 1 in 3000 in $1 \%(\mathrm{w} / \mathrm{v})$ BSA-PBS were added to each well $(100 \mu \mathrm{l})$ and the plates were incubated at $37^{\circ} \mathrm{C}$ for $1 \mathrm{~h}$. After washing, $100 \mu \mathrm{l}$ of $p$-nitrophenyl phosphate (Sigma) $\left(1 \mathrm{mg} \mathrm{ml}^{-1}\right)$ in $50 \mathrm{~mm}$-sodium carbonate buffer, $\mathrm{pH} 9.8$, containing $1 \mathrm{mM}-\mathrm{MgCl}_{2}$ was added to each well. The plate was incubated at $37^{\circ} \mathrm{C}$ for $1 \mathrm{~h}$; the reaction was stopped with $100 \mu \mathrm{l} 3 \mathrm{M}-\mathrm{NaOH}$ and absorbance (at $405 \mathrm{~nm}$ ) was read using a BioRad automatic plate reader.

An inhibition ELISA was used to test for cross reactivity with other bacteroides. Bacteria suspended in $0.5 \mathrm{ml}$ $2 \%(\mathrm{w} / \mathrm{v})$ BSA in PBS to a concentration of $5.0 \times 10^{8}$ c.f.u. $\mathrm{ml}^{-1}$ were mixed with $0.5 \mathrm{ml}$ of hybridoma culture supernate containing McAb Bf 4 and incubated at $4{ }^{\circ} \mathrm{C}$ for $18 \mathrm{~h}$. After centrifugation at $5000 \mathrm{~g}$, triplicate samples $(100 \mu 1)$ of the supernate were tested on ELISA plates coated with B. fragilis NCTC 9343.

An ELISA was used to determine the immunoglobulin class of McAb Bf4. Sheep anti-mouse IgG2a (Serotec), goat anti-mouse IgGI (Sigma), IgG2b (Sigma), IgG3 (Sigma) and IgM (Sigma) were diluted in 50 mM-sodium carbonate buffer, $\mathrm{pH} 9 \cdot 6$, and coated onto PVC microtitre plates as before. Hybridoma culture supernate $(50 \mu \mathrm{l})$ was added to each well; the plates were incubated for $2 \mathrm{~h}$ at $37^{\circ} \mathrm{C}$, and then washed as before. Goat anti-mouse $\operatorname{IgG}$ (specific for light and heavy chains) conjugated to horse-radish peroxidase (Sigma) was diluted 1 in 1000 in $1 \%(\mathrm{w} / \mathrm{v}) \mathrm{BSA}$ in PBS and $50 \mu \mathrm{l}$ was added to each well. The plates were incubated at $37^{\circ} \mathrm{C}$ for $1 \mathrm{~h}$ and washed as above. Orthophenylene diamine (Sigma) substrate $(40 \mathrm{mg}$ ) was dissolved in $100 \mathrm{ml}$ of a solution containing $100 \mathrm{mM}$-citric acid, $200 \mathrm{mM}-\mathrm{Na}_{2} \mathrm{HPO}_{4}$ and $0.01 \%(\mathrm{w} / \mathrm{v}) \mathrm{H}_{2} \mathrm{O}_{2} ; 50 \mu \mathrm{l}$ of the solution was added to each well and the plates were incubated for $30 \mathrm{~min}$; the reaction was stopped with $1 \mathrm{M}-\mathrm{H}_{2} \mathrm{SO}_{4}$ and the absorbance read at $520 \mathrm{~nm}$.

Enrichment for bacterial variants. Capsulate and non-capsulate $B$. fragilis (defined by light microscopy) were separated by Percoll density gradient centrifugation (Patrick \& Reid, 1983).

Preparation of antigens. Antigens were extracted from bacteria by the aqueous phenol method of Westphal \& Luderitz (1954). The aqueous phase was centrifuged at $10000 \mathrm{~g}$ for $30 \mathrm{~min}$ at $4{ }^{\circ} \mathrm{C}$ to remove insoluble material and the supernate was stored at $-20^{\circ} \mathrm{C}$.

Antigens from bacteria were also extracted with a glycine buffer containing EDTA. Bacteria harvested from 
$500 \mathrm{ml}$ broth were resuspended in $10 \mathrm{ml} 3 \mathrm{~mm}$-glycine buffer, pH 5.0 , containing $10 \mathrm{~mm}$-EDTA, and were incubated at $37^{\circ} \mathrm{C}$ for $30 \mathrm{~min}$. Whole cells were removed by centrifugation at $10000 \mathrm{~g}$ for $30 \mathrm{~min}$ at $4{ }^{\circ} \mathrm{C}$ and the extract was stored at $-20^{\circ} \mathrm{C}$. Extracts were treated with protease or sodium periodate by the method of Cousland \& Poxton (1984).

Carbohydrate assay. The anthrone method of Morris (1948), with D-glucose as a standard, was used.

$S D S$-PAGE. This was done on $10 \%$ vertical slab gels using the Laemmli buffer system (Laemmli, 1970) at a constant current of $40 \mathrm{~mA}$ per gel.

Immunoblotting and enzyme immunoassay. The method of Tơwbin et al. (1979) was used with the following modifications. Material was transferred to a nitrocellulose membrane (Transblot TM transfer medium; BioRad) in $25 \mathrm{~mm}$-Tris/ $192 \mathrm{~mm}$-glycine buffer, $\mathrm{pH} 8 \cdot 3$, containing $20 \%(\mathrm{v} / \mathrm{v})$ methanol at $350 \mathrm{~mA}$ for $1.5 \mathrm{~h}$. After washing for $10 \mathrm{~min}$ in Tris-buffered saline (TBS; $20 \mathrm{~mm}$-Tris $/ \mathrm{HCl}, 500 \mathrm{mM}-\mathrm{NaCl}, \mathrm{pH} 7 \cdot 5$ ) the membrane strip containing the protein molecular mass standards was fixed with $1 \%(\mathrm{v} / \mathrm{v})$ acetic acid and stained with amido black. The rest of the membrane was placed in $3 \%(\mathrm{w} / \mathrm{v})$ BSA in TBS (BSA-TBS) for $16 \mathrm{~h}$ at $4{ }^{\circ} \mathrm{C}$. It was then transferred into hybridoma culture supernate, or an appropriately diluted mouse derived antiserum, and incubated for $2 \mathrm{~h}$ at room temperature. After three washes in $0.025 \%(\mathrm{v} / \mathrm{v})$ Tween 20 in TBS, the membrane was placed in goat anti-mouse IgM-alkaline phosphatase conjugate (Tago) specific for the Mu chain, then diluted 1 in 3000 in $1 \%$ ( $w / v)$ BSA in TBS and incubated for $1 \mathrm{~h}$ at room temperature. The membrane was washed three times in Tween 20-TBS and placed in $50 \mathrm{~mm}$-Tris/ $\mathrm{HCl}$ buffer, $\mathrm{pH} 8 \cdot 2$, containing Fast Red $\left(3 \mathrm{mg} \mathrm{ml}^{-1}\right)$ and naphthol-AS-MX-phosphate $(0 \cdot 2$ $\mathrm{mg} \mathrm{ml}^{-1}$ ). Colour development took place in 5-15 min, and the reaction was then stopped by washing in distilled water. All the above steps were done with gentle agitation throughout.

Immunogold labelling and electron microscopy. Bacteria were washed twice in $100 \mathrm{~mm}$-sodium cacodylate $/ \mathrm{HCl}$ buffer, $\mathrm{pH} 7.2(\mathrm{CB})$, and fixed in CB containing $2 \%(\mathrm{v} / \mathrm{v})$ paraformaldehyde and $0 \cdot 1 \%(\mathrm{v} / \mathrm{v})$ glutaraldehyde for $1 \mathrm{~h}$ at $4{ }^{\circ} \mathrm{C}$. The cells were again washed in $\mathrm{CB}$, dehydrated in graded alcohols and embedded in LR white resin. For gold labelling, ultrathin sections on nickel grids were treated with McAb Bf4 followed by goat anti-mouse IgM$40 \mathrm{~nm}$ gold conjugate (Janssen). The grids were washed in $0 \cdot 1 \%(\mathrm{v} / \mathrm{v})$ BSA-TBS, pH $8 \cdot 2$, and rinsed in distilled water. They were then stained with uranyl acetate and lead citrate and examined with a Philips 301 transmission electron microscope. Ruthenium red staining was done as described previously (Patrick et al., 1986) before the bacteria were embedded in LR white resin.

Immunofluorescence microscopy. The method was described by Reid et al. (1985).

\section{RESULTS}

\section{$S D S-P A G E$ and immunoblotting of the phenol-water extract}

Reactions with polyclonal mouse antiserum. SDS-PAGE and immunoblotting with homologous anti-B. fragilis NCTC 9343 antiserum detected multiple bands (Fig. 1c). A diffuse staining pattern and a series of closely spaced discrete bands (arrowed S) were detected at the top of the blot. A series of regularly spaced discrete bands was observed in the middle of the blot (labelled $\mathrm{R}+\mathrm{n}$ ). At least two heavily stained bands were seen in the lower region of the blot.

Reaction with $M c A b B f 4$. Staining was observed only in the high molecular mass region when $\mathrm{McAb} \mathrm{Bf} 4$ was used for immunoblotting (Fig. $1 b$ ). McAb Bf4 reacted strongly with both the diffuse staining region and the closely spaced discrete bands.

Treatment of antigen with protease, periodate and heat. The structure recognized by $\mathrm{McAb} \mathrm{Bf} 4$ resisted protease digestion (result not shown) and the immunoblot was identical to that for the control antigen (Fig. 1 b). Oxidation of the antigen preparation with sodium periodate destroyed the $\mathrm{Bf} 4$ antigenic determinant (Fig. $1 \mathrm{a}$ ). Heating at $100^{\circ} \mathrm{C}$ for $3 \mathrm{~min}$ did not destroy the structure containing the Bf4 epitope.

\section{SDS-PAGE and immunoblotting of glycine-EDTA extract}

Immunoblotting of the glycine-EDTA extract after SDS-PAGE with McAb Bf4 revealed multiple closely spaced discrete bands and at least four extra bands in the high molecular mass region of the blot (Fig. $2 b, d$ ). Protease treatment did not affect the closely stained bands but the extra bands in the top region of the blot disappeared (Fig. $2 c$ ). Oxidation with sodium periodate removed the closely spaced bands, but multiple faintly immunoreactive bands were detected in the lower region of the blot after treatment (Fig. 2a).

\section{ELISA}

$\mathrm{McAb} \mathrm{Bf} 4$ was identified as an IgM antibody using a sandwich ELISA.

Inhibition studies were done to test the reactivity of $\mathrm{McAb} \mathrm{Bf} 4$ with other Bacteroides species 


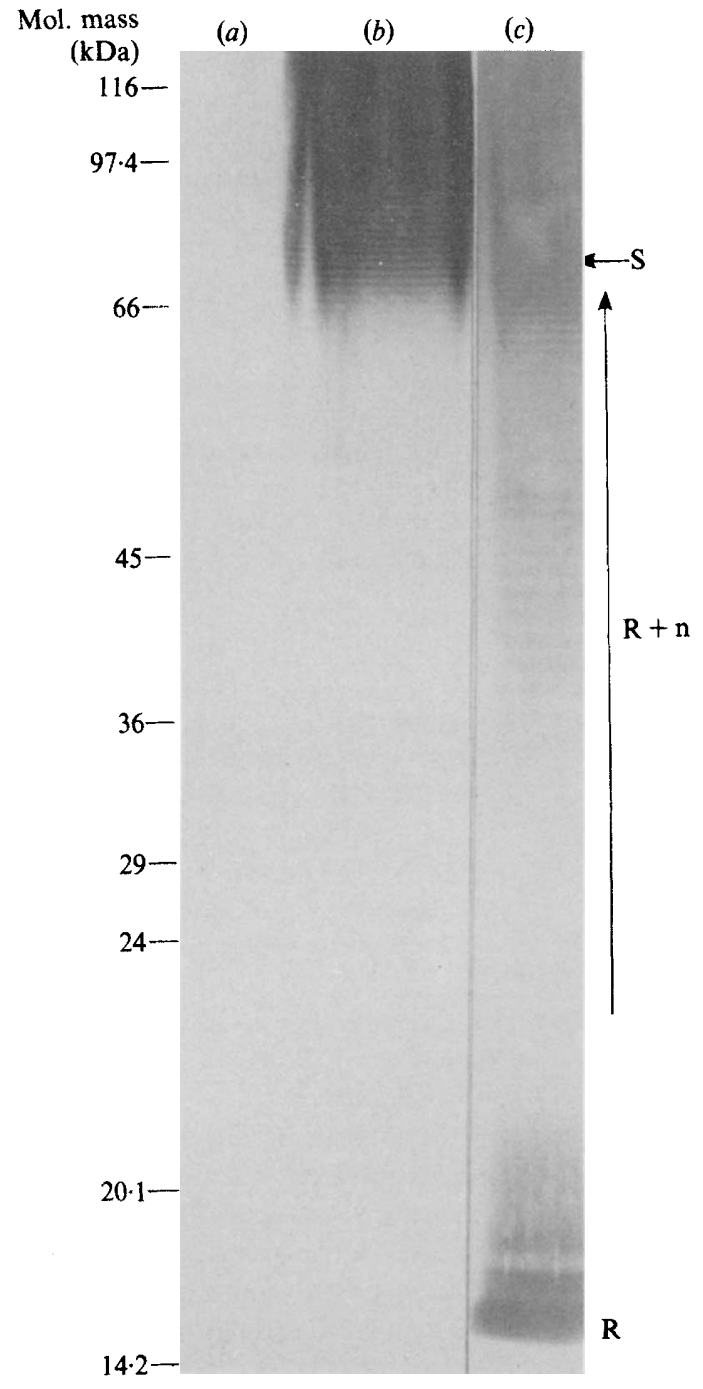

Fig. 1. SDS-PAGE and immunoblot analysis of aqueous phase antigens extracted from $B$. fragilis NCTC 9343 by the hot phenol-water method. Periodate treated antigen $(a)$ and control $(b)$ were blotted with $\mathrm{McAb} \mathrm{Bf} 4$; control antigen was also blotted with immune mouse antiserum $(c)$. Carbohydrate loaded was $15 \mu \mathrm{g}$ per lane.

and strains. Also, cells of $B$. fragilis NCTC 9343 recovered from the various interfaces of a Percoll discontinuous density gradient were tested for expression of the $\mathrm{Bf} 4$ antigen.

B. ovatus ATCC 8483, B. distasonis ATCC 8503 and B. thetaiotaomicron NCTC 10582 did not inhibit the ELISA. Four reference strains and nine clinical isolates of $B$. fragilis were also tested. Inhibition was detected only with the homologous strain of NCTC 9343.

Bacteria recovered from the $0-20 \%, 20-40 \%$ and $40-60 \%$ interfaces of a Percoll discontinuous density gradient inhibited the ELISA, but cells from the $60-80 \%$ interface did not. No attempt was made to measure the minimum number of cells required to inhibit the assay.

\section{Immunofluorescence and immunoelectron microscopy}

Immunofluorescence and immunoelectron microscopy of cells taken from the four interfaces of the Percoll gradient gave the same pattern of labelling. The absence of the Bf 4 epitope from the $60-80 \%$ interface was confirmed. Cells from this interface are apparently non-capsulate by light microscopy, but have an extracellular electron dense layer by electron microscopy (Patrick 
(a)

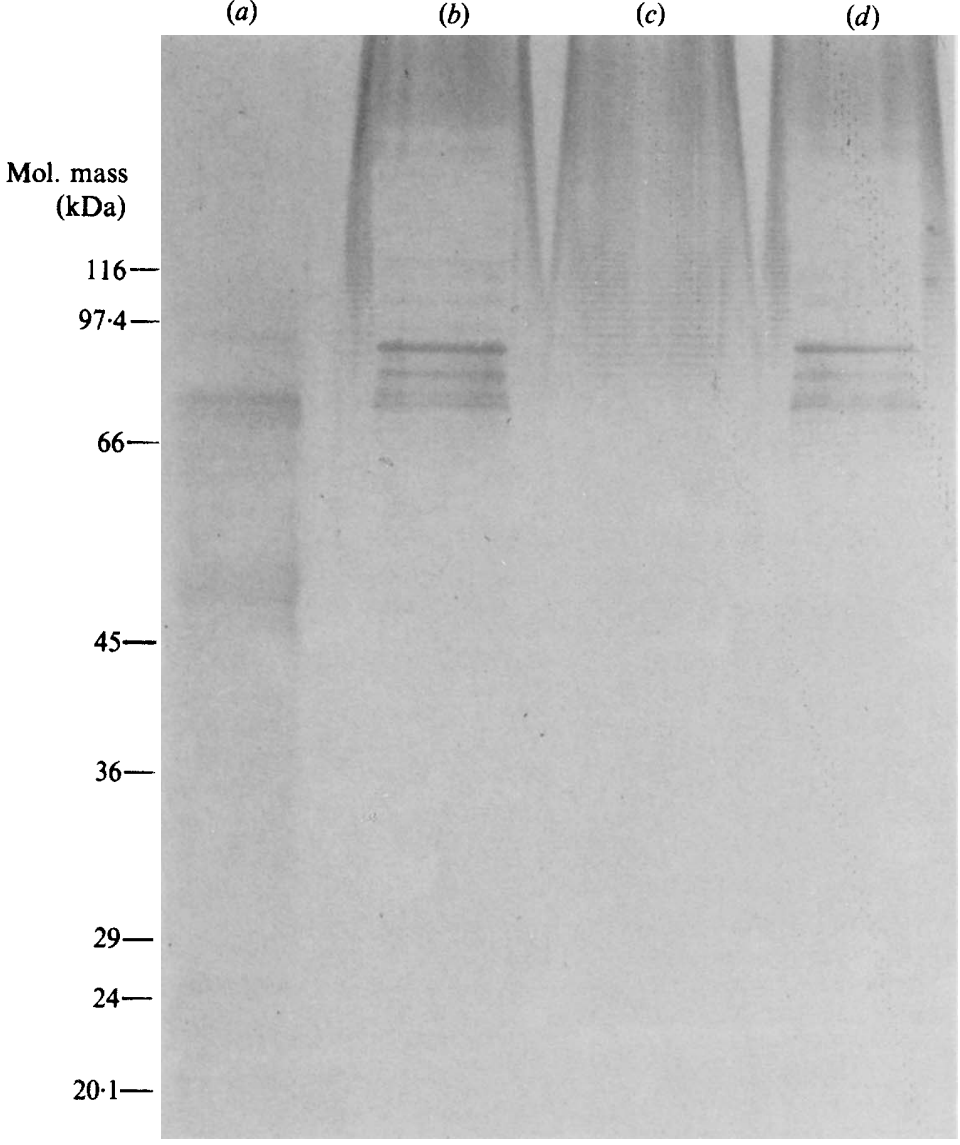

Fig. 2. SDS-PAGE and immunoblot analysis of antigens extracted from B. fragilis NCTC 9343 with mild heat and EDTA-glycine buffer, pH 5.0. Antigen treatments were periodate $(a)$ with control $(b)$, and protease $(c)$ with control $(d)$. Carbohydrate loaded was $50 \mu \mathrm{g}$ per lane.

et al., 1986). A low proportion of cells from the $0-20 \%$ (Fig. $3 a$ ) and $40-60 \%$ (not illustrated) interfaces were labelled, but cells from the $20-40 \%$ interface were enriched for the Bf 4 epitope (Fig. $3 b$ ). The surface structures of $B$. fragilis are not easily resolved with the fixation procedures required to preserve the reactivity of the antigens for immunoelectron microscopy: therefore duplicate samples were stained with ruthenium red. The results indicate that the Bf 4 epitope is associated with the marginal fibrous network present on cells from the $20-40 \%$ interface (Fig. $3 d$ ), but not with the extensive fibrous network which is present on cells from the $0-20 \%$ interface (Fig. 3c). Two other monoclonal antibodies (Bf1; Reid et al., 1985 and Bf2; not illustrated) give a similar labelling pattern for each of the interfaces and could not be related to a specific surface structure.

Cells from the $0-20 \%$ interface were grown for $24 \mathrm{~h}$ in chambers implanted in the mouse peritoneal cavity (Patrick et al., 1984). These populations were not enriched for the Bf4 epitope (Fig. 4). Similar labelling patterns were seen with these populations before and after in vivo passage (Figs $3 a$ and 4).

\section{DISCUSSION}

Immunoblotting and immunoelectron microscopy showed that $\mathrm{McAb} \mathrm{Bf} 4$ reacted with an epitope on a high molecular mass surface polysaccharide. This structure was distinct from the 

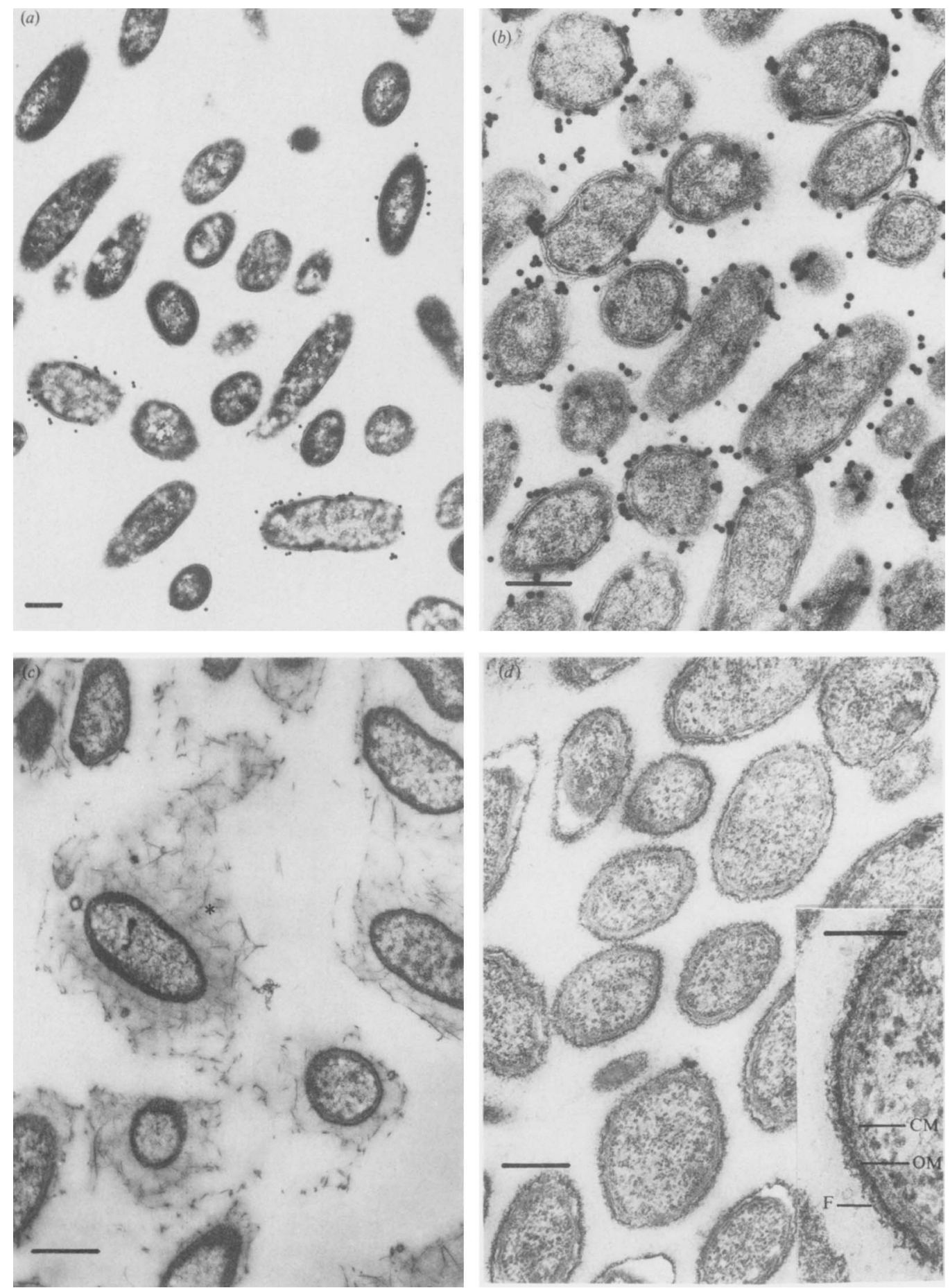

Fig. 3. Electron micrographs of cells of $B$. fragilis NCTC 9343 recovered from the interfaces of a Percoll discontinuous density gradient. (a) Cells from the $0-20 \%$ interface labelled with McAb Bf4 and antimouse IgM immunogold conjugate; note the low proportion of gold labelled cells. (b) Cells from the 20$40 \%$ interface labelled as in $(a)$; note that most of the cells are labelled. (c) Cells from the $0-20 \%$ interface stained with ruthenium red; note the extensive fibrous network $\left(^{*}\right)$. (d) Cells from the $20-40 \%$ interface stained with ruthenium red; note the marginal fibrous network $(F)$ adjacent to the outer membrane $(\mathrm{OM}) ; \mathrm{CM}$, cytoplasmic membrane. Bar $=0.5 \mu \mathrm{m}$ in main micrographs and $100 \mathrm{~nm}$ in Fig. 3(d) insert. 


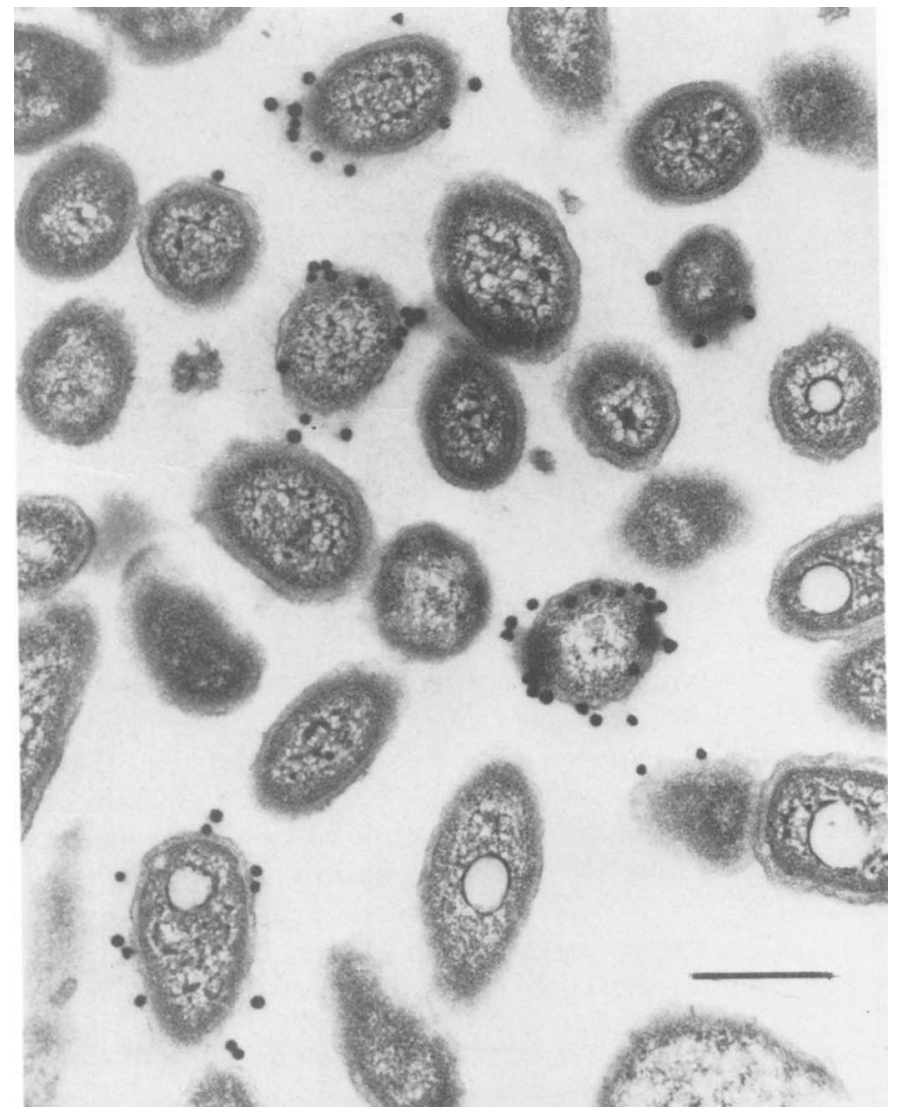

Fig. 4. Electron micrograph of cells of $B$. fragilis NCTC 9343 taken from the $0-20 \%$ interface of a Percoll gradient and passaged for $24 \mathrm{~h}$ in the mouse peritoneal cavity. Cells were labelled with $\mathrm{McAb} \mathrm{Bf} 4$ and anti-mouse IgM immunogold conjugate. Note the low proportion of cells labelled. Bar $=0.5 \mu \mathrm{m}$.

extensive fibrous network, present on cells recovered from the $0-20 \%$ interface of a Percoll density gradient, and the electron dense layer, present on cells from the $60-80 \%$ interface. It was, however, associated with the marginal fibrous network observed on cells from the $20-40 \%$ interface. These results indicate that structures which look different by electron microscopy may also be antigenically different. Immunogold labelling of cells grown in the mouse peritoneal cavity gave a heterogeneous labelling pattern which indicates that this epitope was not selected in vivo.

ELISA inhibition studies showed that McAb Bf4 recognized a type-specific surface antigen. Kasper et al. (1983) showed that extracted capsular polysaccharide from $B$. fragilis NCTC 9343 was chemically and antigenically different from that of $B$. fragilis ATCC 23745, and typespecific epitopes were identified in the capsular material. This capsular material was detected in the high molecular mass region of a $20 \%(\mathrm{w} / \mathrm{v})$ acrylamide gel by silver staining (Weintraub et al., 1985). Weintraub et al. (1985) also extracted LPS from $B$. fragilis NCTC 9343 by the hot phenolwater method and subsequently extracted the aqueous phase with a phenol-chloroformpetroleum (PCP) mixture: rough LPS only was detected with SDS-PAGE and silver staining. However, $B$. fragilis NCTC 9343 could also contain smooth LPS with lor. " polysaccharide side chains since the PCP extraction procedure preferentially extracts lipophilic rough LPS while smooth LPS is excluded (Galanos et al., 1969). Cousland \& Poxton (1983) have observed heterogeneity in LPS extracted from a variety of $B$. fragilis strains by the hot phenol-water method. They separated LPS extracted from $B$. fragilis GNAB 92 by electrophoresis on a $10 \%$ $(w / v)$ acrylamide gel and detected possible smooth LPS (labelled S) in the top of the blot. 
McAb Bf4 reacted with B. fragilis NCTC 9343 antigens in this region of the blot. McAb Bf4 did not react with the typical LPS 'ladder' (Fig. 1 $b$, labelled $\mathrm{R}+\mathrm{n}$ ) in the middle of the blot, suggesting that either the Bf4 epitope was not part of a repeating O-side-chain or the concentration of the LPS containing short O-side-chains was below a detectable level when using $\mathrm{McAb} \mathrm{Bf} 4$. The epitope could be associated with a repeating capsular polysaccharide unit but the polymer would need to be covalently linked to a lipid to bind SDS, or have a negative charge for electrophoresis to occur.

E. coli LPS formed non-covalently linked multimers during SDS-PAGE when $0 \cdot 1 \%(\mathrm{w} / \mathrm{v})$ SDS was used in $15 \%(\mathrm{w} / \mathrm{v})$ acrylamide separating gels (Peterson \& McGroarty, 1985). The multimers dissociated when $0.5 \%(\mathrm{w} / \mathrm{v})$ SDS was used or when separating gels were overlayed with butanol and left overnight. McAb Bf4 could also be reacting with multimers of $B$. fragilis NCTC 9343 LPS. The SDS-PAGE conditions were not altered in this study but the hypothesis could be tested by increasing the SDS concentrations in both the sample buffer and the separating gel, or by electro-eluting the high molecular mass material from the top section of the gel, and reanalysing the material by SDS-PAGE and immunoblotting with McAb Bf4.

Poxton et al. (1985) detected protein-LPS complexes when outer membrane extracts of Pseudomonas aeruginosa were immunoblotted with McAbs specific for the LPS O-antigen. This report describes a similar observation using a glycine-EDTA extract of $B$. fragilis NCTC 9343 and immunoblotting with $\mathrm{McAb} \mathrm{Bf} 4$. There are a number of possible explanations for this phenomenon. First, protein-LPS complexes released by the glycine-EDTA treatment could resist solubilization with SDS. Second, antigens could be completely solubilized by detergent but co-migrate to the same position in the gel. Third, solubilized high molecular mass peptides could become entangled with long polysaccharide chains containing the $\mathrm{Bf} 4$ epitope during electrophoresis. The stability of antigen complexes could be investigated by affinity chromatography. We now hope to purify the polysaccharide containing the Bf 4 epitope using affinity chromatography. The structure could then be chemically analysed to determine whether it is a polysaccharide or a lipopolysaccharide.

John H. Reid and this research were supported by a Wellcome Trust Grant (no. 12491/1.5/BMO/ard).

\section{REFERENCES}

BABB, J. I. \& CUmmins, C. S. (1978). Encapsulation of Bacteroides species. Infection and Immunity 19, 10881093.

Connolly, J. C., McClean, C. \& Tabaqchali, S. (1984). The effect of capsular polysaccharide of Bacteroides fragilis on polymorph function and serum killing. Journal of Medical Microbiology 17, 259-271.

Cousland, G. \& Poxton, I. R. (1983). Analysis of lipopolysaccharides of Bacteroides fragilis by sodium dodecyl sulphate-polyacrylamide gel electrophoresis and electroblot transfer. FEMS Microbiology Letters 20, 461-465.

Cousland, G. \& Poxton, I. R. (1984). Crossed immunoelectrophoresis and enzyme-linked immunosorbent assay of the cell-surface antigens of Bacteroides fragilis. Journal of General Microbiology 130, 645-655.

DUERDEN, B. I. (1980). The identification of Gram negative anaerobic bacilli isolated from clinical infections. Journal of Hygiene 84, 69.

Galanos, C., LUdERITZ, O. \& WestPhal, O. (1969). A new method for the extraction of R lipopolysaccharides. European Journal of Biochemistry 9, 245-249.

Gorbach, L. S. \& Bartlett, J. G. (1974). Anaerobic infections. New England Journal of Medicine 290, 1177-1184.
HofsTAD, T. (1984). Pathogenicity of anaerobic Gramnegative rods: possible mechanisms. Reviews of Infectious Diseases 6, 189-199.

KASPER, D. L. (1976). The polysaccharide capsule of Bacteroides fragilis subspecies fragilis: immunochemical and morphological definition. Journal of Infectious Diseases 133, 79-87.

Kasper, D. L., Onderdonk, A. B., Reinap, B. G. \& LINDBERG, A. A. (1980). Variations of Bacteroides fragilis with in vitro passage: presence of an outer membrane-associated glycan and loss of capsular antigen. Journal of Infectious Diseases 142, 750756.

KaSPER, D. L., Weintraub, A. B., Lindberg, A. A. \& LONNGREN, J. (1983). Capsular polysaccharides and lipopolysaccharides from two Bacteroides fragilis reference strains: chemical and immunochemical characterization. Journal of Bacteriology 153, 991997.

Lambe, D. W., Mayberry-Carson, K. J. S., FerguSON, K. P. \& Costerson, J. W. (1984). Morphological stabilization of the glycocalyces of 23 strains of five Bacteroides species using specific antisera. Canadian Journal of Microbiology 30, 809-819.

LAEMMLI, U. K. (1970). Cleavage of structural proteins during the assembly of the head of bacteriophage T4. Nature, London 227, 680-685. 
Lemke, H., Hammerling, G. J., Hohmann, C. \& RAJEWSKY, K. (1978). Hybrid cell lines secreting monoclonal antibody specific for major histocompatibility antigens of the mouse. Nature, London 271, 249-251.

Linko-Kettunen, L., Arstila, P., Jalkanen, M., Jousimies-Somer, H., Lassila, O., Lehtonen, O. P., Weintraub, A. \& Viljanen, M. K. (1984). Monoclonal antibodies to Bacteroides fragilis lipopolysaccharide. Journal of Clinical Microbiology 20, 519524.

MORRIS, D. L. (1948). Quantitative determination of carbohydrates with Dreywood's anthrone reagent. Science 107, 254-255.

Onderdonk, A. B., Kasper, D. L., Cisneros, R. L. \& BARTLETT, J. G. (1977). The capsular polysaccharide of Bacteroides fragilis as a virulence factor: comparison of the pathogenic potential of encapsulated and unencapsulated strains. Journal of Infectious Diseases 136, 82-89.

PATRICK, S. \& REID, J. H. (1983). Separation of capsulate and non-capsulate Bacteroides fragilis on a discontinuous density gradient. Journal of Medical Microbiology 16, 239-241.

PATRICK, S., ReID, J. H. \& LARKin, M. J. (1984). The growth and survival of capsulate and non-capsulate Bacteroides fragilis in vivo and in vitro. Journal of Medical Microbiology 17, 237-246.

Patrick, S., ReId, J. H. \& Coffey, A. (1986). Capsulation of in vitro and in vivo grown Bacteroides species. Journal of General Microbiology 132, 10991109.

Peterson, A. A. \& McGroarty, E. J. (1985). High- molecular-weight components in lipopolysaccharides of Salmonella typhimurium, Salmonella minnesota and Escherichia coli. Journal of Bacteriology 162, 738745.

Poxton, I. R., Bell, G. T. \& Barclay, G. R. (1985). The association on SDS-polyacrylamide gels of lipopolysaccharide and outer membrane proteins of Pseudomonas aeruginosa as revealed by monoclonal antibodies and Western blotting. FEMS Microbiology Letters 27, 247-251.

Reid, J. H., Patrick, S., Dermott, E., Trudgett, A. \& TABAQCHALI, S. (1985). Investigation of antigenic expression of Bacteroides fragilis by immunogold labelling and immunoblotting with a monoclonal antibody. FEMS Microbiology Letters 30, 289293.

VAN TASSELl, R. L. \& WiLkins, T. D. (1978). Isolation of auxotrophs of Bacteroides fragilis. Canadian Journal of Microbiology 24, 1619-1621.

Towbin, H., Staehelin, T. \& Gordon, J. (1979). Electrophoretic transfer of proteins from polyacrylamide gels to nitrocellulose sheets: procedure and some applications. Proceedings of the National Academy of Sciences of the United States of America 76, 4350-4354.

Weintraub, A., Larsson, B. E. \& Lindberg, A. A. (1985). Chemical and immunochemical analyses of Bacteroides fragilis lipopolysaccharides. Infection and Immunity 49, 197-201.

Westphal, O. \& Luderitz, O. (1954). Chemische Erforschung von lipopolysacchariden Gramnegativer Bakterien. Angewandte Chemie 66, 407417 . 